\title{
Effect of foliar feeding on yield and fruit quality of three melon (Cucumis melo L.) cultivars
}

\author{
Anna Zaniewicz-Bajkowska, Jolanta Franczuk, Edyta Kosterna \\ Faculty of Agriculture, University of Podlasie \\ B. Prusa 14, 08-110 Siedlce, Poland \\ e-mail: warzywa@ap.siedlce.pl
}

Key w ord s: average fruit weight, flesh thickness, foliar fertilizers, fruit flavour

\begin{abstract}
The effect of foliar feeding with two fluid multicomponent fertilizers was investigated: Florovit and Ekolist Warzywa + Urea on the yield and quality of three medium-fruit-size melon cultivars ('Charentais $\mathrm{F}_{1}$ ', 'Melba', 'Fiesta'). Weather conditions in the consecutive years of the study had a significant influence on the yield level and quality of fruit. A higher yield of better quality was achieved in the years 2005 and 2007. That period was characterised by relatively high air temperature and low rainfall towards the end of the growing period of melon. The fertilizers applied in the experiment significantly influenced melon yielding. The plants fertilized with Ekolist Warzywa + Urea provided a higher marketable yield of melon fruit than the plants fertilized with Florovit. When applied, this fertilizer also caused an increase in flesh thickness and fruit flavour as compared with Florovit feeding. Foliar feeding with both studied patterns increased the average fruit weight and number of marketable fruit as compared to the non-fertilized treatment. Among the studied cultivars, 'Fiesta' gave the highest marketable yield and the best quality fruit.
\end{abstract}




\section{INTRODUCTION}

Foliar feeding of plants is an important supplementation of soil fertilization, especially under conditions of limited uptake of nutrients from the soil (Czuba 1993). According to a number of authors, soil fertilization, when combined with foliar feeding, improves both yields and the biological value of vegetables (Nurzyński 1997, Osińska and Kołota 1998, Wójcik 1998, Biesiada et al. 2000, Kołota and Osińska 2000, Mareczek et al. 2000).

In horticultural practice, foliar fertilization is also recommended as the most effective method of supplying plants with nutrients under deficiency conditions (Trejo-Téllez et al. 2007). Moreover, in their studies Mazur (1992), Kołota and Biesiada (2000) indicated the possibility of limiting mineral fertilizer use by means of application of foliar fertilization.

The objective of the study was to determine the effect of foliar feeding with Florovit and Ekolist Warzywa + Urea on the yield and fruit quality of three melon cultivars.

\section{MATERIAL AND METHODS}

The field experiment was conducted in 2005-2007 at the greenhouse complex belonging to the University of Podlasie in Siedlce. The experiment was established as randomised blocks with four replications. The experiment site was anthropogenic soil with hortisol properties that has been used as a part of a horticultural farm for many years. It was a neutral soil characterized by a humus level of approximately $40 \mathrm{~cm}$ and average organic carbon content of $2.2 \%$ (Tab. 1).

Table 1. Characteristics of soil conditions before experiment placing

\begin{tabular}{lcccccccc}
\hline \multirow{2}{*}{ Year } & \multirow{2}{*}{$\mathrm{pH}$} & $\mathrm{C}-$-org $\%$ & ${\mathrm{~N}-\mathrm{NO}_{3}}$ & $\mathrm{~N}^{2} \mathrm{NH}_{4}$ & $\mathrm{P}$ & $\mathrm{K}$ & $\mathrm{Ca}$ & $\mathrm{Mg}$ \\
\hline 2005 & 6.9 & 2.3 & 15 & 26 & 23 & 68 & 856 & 29 \\
2006 & 7.2 & 2.0 & 9 & 20 & 18 & 81 & 913 & 26 \\
2007 & 6.6 & 2.3 & 13 & 19 & 20 & 60 & 887 & 28 \\
\hline Mean & 6.9 & 2.2 & 12 & 22 & 20 & 70 & 885 & 28 \\
\hline
\end{tabular}

The available phosphorus and potassium contents were below the lowest optimum limit whereas nitrogen, magnesium and calcium contents were slightly above this limit for field-grown cucumber (Sady 2000). These standards were also assumed for field-grown melon. Basic soil preplant fertilization included Azofoska at a rate of $10 \mathrm{~kg}$ per $100 \mathrm{~m}^{2}$ of cultivated area. 
The experiment involved a study of the effect of foliar feed formulation application (control without foliar feeding, double foliar application of Florovit at the concentration of $0.25 \%$, double foliar application of Ekolist Warzywa at the concentration of $0.5 \%$ with addition Urea at the concentration of $0.1 \%$ ) on the level and quality of yield of three melon cultivars ('Charentais $\mathrm{F}_{1}$ ', 'Melba', 'Fiesta') characterised by an average fruit weight of $0.5-0.7 \mathrm{~kg}$. Ekolist Warzywa contains $(\% \mathrm{~m} / \mathrm{m}): \mathrm{N}-4, \mathrm{MgO}-5, \mathrm{~S}-4.3, \mathrm{~B}-0.56, \mathrm{Cu}-0.60, \mathrm{Fe}-0.67, \mathrm{Mn}-1, \mathrm{Mo}$ $-0.004, \mathrm{Zn}-0.60$. Florovit contains $(\%)$ : $\mathrm{N}-3, \mathrm{~K}_{2} \mathrm{O}-2$; and microelements $\left(\mathrm{mg} \mathrm{dm}^{-3}\right): \mathrm{Cu}-70, \mathrm{Fe}-400, \mathrm{Mn}-170, \mathrm{Mo}-20, \mathrm{Zn}-150$.

The seeds were sown in the first ten days of May in peaty-cellulose pots of $8 \mathrm{~cm}$ in diameter filled with peaty substratum. The melon seedlings were grown in a non-heated greenhouse. Before transplanting the seedlings to the field they were hardened off and vine tops were removed so that each plant had three leaves. The seedlings were moved permanently outdoors and planted on 6 June in 2005 and 2006, and on 5 June in 2007. On each plot, eight plants were planted at a distance of $0.8 \times 1.2 \mathrm{~m}$. After the seedlings were planted, the plants were shielded with a polyprophylene fibre cover, which was removed at the beginning of florescence. When the fruit buds were of walnut size, excessive buds were removed with the largest eight left on the plant. Moreover, fruit-bearing vines were shortened to two leaves located close to the bud and vines bearing no fruit were removed.

At the beginning of florescence and following cutting, the solutions of liquid foliar Florovit and Ekolist Warzywa + Urea belonging to multi-component fertilizers were applied.

The harvest was started during the second ten days of August and was finished in the second ten days of September. Harvest of fruit was performed once a week as fruit ripened. During the harvest the marketable yield, average weight of marketable fruit, number of marketable fruit, and flesh thickness were determined, as well as fruit flavour, which was assessed according to a scale 1-6 by six persons (a score of six was considered the tastiest fruit).

The results of the experiment were analysed statistically by means of the analysis of variance. The significance of differences was checked using the Tukey test at the significance level of $p=0.05$.

Weather conditions in the years of the study varied considerably. The least favourable year for melon growth was 2006 (Tab. 2). It was characterised by relatively high mean air temperature in comparison with the other years of the study in addition to a very irregular precipitation pattern. After drought in June and July, which curtailed plant growth and development, precipitation in August amounted to $255 \mathrm{~mm}$. In 2005 and 2007, the observed precipitation favoured melon growth and yields. The first half of the growing season was humid and it was followed by lower precipitation in August, which was beneficial for fruit ripening. 
August 2007 was much warmer than in the other years of study, which improved melon fruit quality.

Table 2. Mean air temperature and precipitation sums in the vegetation period of melon

\begin{tabular}{lcccccrrc}
\hline \multirow{2}{*}{ Year } & \multicolumn{4}{c}{ Temperature $\left({ }^{\circ} \mathrm{C}\right)$} & \multicolumn{3}{c}{ Precipitation $(\mathrm{mm})$} \\
\cline { 2 - 9 } & June & July & August & September & June & July & August & September \\
\hline 2005 & 15.4 & 19.7 & 16.9 & 14.6 & 48.9 & 94.1 & 24.9 & 18.0 \\
2006 & 16.6 & 21.8 & 17.7 & 15.1 & 25.7 & 8.6 & 255.5 & 28.3 \\
2007 & 18.2 & 18.5 & 18.6 & 13.1 & 59.9 & 70.2 & 31.1 & 67.6 \\
\hline Mean 1951-1990 & 16.2 & 17.6 & 16.9 & 12.7 & 69.3 & 70.6 & 59.8 & 48.2 \\
\hline
\end{tabular}

\section{RESULTS AND DISCUSSION}

Weather conditions in consecutive years of the study had a significant influence on the level of marketable yield, as well as average weight and number of marketable fruit (Tabs 3-5). The significantly highest marketable yield $\left(2.62 \mathrm{~kg} \mathrm{~m}^{-2}\right)$, average fruit weight $(0.77 \mathrm{~kg})$ and the number of fruit $\left(3.32\right.$ fruit $\left.\mathrm{m}^{-2}\right)$ were obtained in 2007, when weather conditions favoured melon cultivation. In the least favourable year, 2006, the yield and other analysed parameters were lower by about $1.67 \mathrm{~kg}$ $\mathrm{m}^{-2}, 0.33 \mathrm{~kg}$ and 1.20 fruit $\mathrm{m}^{-2}$, respectively.

Table 3. Marketable yield depending on cultivar of melon and foliar feeding $\left(\mathrm{kg} \mathrm{m}^{-2}\right)$

\begin{tabular}{lccccc}
\hline \multirow{2}{*}{ Year } & \multirow{2}{*}{ Foliar feeding } & \multicolumn{3}{c}{ Cultivar } & \multirow{2}{*}{ Mean } \\
\cline { 3 - 5 } 2005 & I* & 1.90 & 0.77 & 1.43 & 1.37 \\
& II & 1.93 & 0.80 & 2.13 & 1.62 \\
& III & 2.00 & 0.90 & 2.03 & 1.64 \\
\hline Mean & & 1.94 & 0.82 & 1.86 & 1.54 \\
\hline \multirow{2}{*}{2006} & I & 0.99 & 0.66 & 0.83 & 0.83 \\
& II & 1.15 & 0.68 & 0.91 & 0.91 \\
\hline Mean & III & 1.54 & 0.79 & 0.97 & 1.10 \\
\hline \multirow{2}{*}{2007} & & 1.23 & 0.71 & 0.90 & 0.95 \\
& I & 1.57 & 1.77 & 2.53 & 1.96 \\
\hline Mean & II & 1.77 & 2.13 & 4.17 & 2.69 \\
\multirow{2}{*}{ Mean for } & III & 2.13 & 1.73 & 5.80 & 3.22 \\
foliar feeding & I & 1.82 & 1.88 & 4.17 & 2.62 \\
\hline Mean for cultivar & II & 1.49 & 1.07 & 1.60 & 1.39 \\
\hline LSD & & 1.62 & 1.20 & 2.40 & 1.74 \\
\hline
\end{tabular}

$\mathrm{LSD}_{0.05}$ for: years $=0.29$; foliar feeding $=0.29$; cultivar $=0.21$; year $\times$ foliar feeding $=0.50$;

year $\times$ cultivar $=0.37$; foliar feeding $\times$ cultivar $=0.34$

*I - control; II - Florovit; III - Ekolist + Urea 
Table 4. Average weight of marketable fruit depending on cultivar of melon and foliar feeding $(\mathrm{kg})$

\begin{tabular}{|c|c|c|c|c|c|}
\hline \multirow{2}{*}{ Year } & \multirow{2}{*}{ Foliar feeding } & \multicolumn{3}{|c|}{ Cultivar } & \multirow{2}{*}{ Mean } \\
\hline & & 'Charentais $\mathrm{F}_{1}$ ' & 'Melba' & 'Fiesta' & \\
\hline \multirow{3}{*}{2005} & $I^{*}$ & 0.61 & 0.59 & 0.62 & 0.61 \\
\hline & II & 0.56 & 0.64 & 0.74 & 0.65 \\
\hline & III & 0.58 & 0.65 & 0.76 & 0.66 \\
\hline \multirow[t]{2}{*}{ Mean } & & 0.58 & 0.63 & 0.71 & 0.64 \\
\hline & I & 0.47 & 0.41 & 0.36 & 0.41 \\
\hline \multirow[t]{2}{*}{2006} & II & 0.53 & 0.40 & 0.38 & 0.44 \\
\hline & III & 0.60 & 0.42 & 0.39 & 0.47 \\
\hline \multirow[t]{2}{*}{ Mean } & & 0.53 & 0.41 & 0.38 & 0.44 \\
\hline & I & 0.48 & 0.88 & 0.67 & 0.68 \\
\hline \multirow[t]{2}{*}{2007} & II & 0.53 & 0.76 & 0.94 & 0.74 \\
\hline & III & 0.72 & 0.85 & 1.11 & 0.89 \\
\hline \multicolumn{2}{|l|}{ Mean } & 0.58 & 0.83 & 0.91 & 0.77 \\
\hline \multirow{3}{*}{$\begin{array}{l}\text { Mean for } \\
\text { foliar feeding }\end{array}$} & I & 0.52 & 0.63 & 0.55 & 0.57 \\
\hline & II & 0.54 & 0.60 & 0.69 & 0.61 \\
\hline & III & 0.63 & 0.64 & 0.75 & 0.67 \\
\hline \multicolumn{2}{|l|}{ Mean for cultivar } & 0.56 & 0.62 & 0.66 & 0.61 \\
\hline
\end{tabular}

Table 5. Number of marketable fruit depending on cultivar of melon and foliar feeding (fruit $\mathrm{m}^{-2}$ )

\begin{tabular}{lccccc}
\hline \multirow{2}{*}{ Year } & \multirow{2}{*}{ Foliar feeding } & \multicolumn{3}{c}{ Cultivar } & \multirow{2}{*}{ Mean } \\
\cline { 3 - 5 } 2005 & I* & 3.13 & 1.28 & 2.36 & 2.26 \\
& II & 3.45 & 1.28 & 2.87 & 2.53 \\
\hline Mean & III & 3.45 & 1.40 & 2.68 & 2.51 \\
\hline \multirow{2}{*}{2006} & & 3.34 & 1.32 & 2.64 & 2.43 \\
\hline Mean & I & 2.08 & 1.62 & 2.28 & 1.99 \\
& II & 2.16 & 1.70 & 2.38 & 2.08 \\
2007 & III & 2.50 & 1.86 & 2.48 & 2.28 \\
\hline \multirow{2}{*}{ Mean } & & 2.25 & 1.73 & 2.38 & 2.12 \\
\hline \multirow{2}{*}{ Mean for } & I & 3.24 & 2.02 & 3.79 & 3.02 \\
foliar feeding & II & 3.42 & 2.81 & 4.40 & 3.54 \\
Mean for cultivar & III & 2.99 & 2.02 & 5.20 & 3.40 \\
\hline
\end{tabular}

$\mathrm{LSD}_{0.05}$ for: years $=0.24$; foliar feeding $=0.24$; cultivar $=0.16$; year $\times$ foliar feeding $=$ n.s.; year $\times$ cultivar $=0.28$; foliar feeding $\times$ cultivar $=$ n.s.

*Explanations: see Table 3 
Marketable yield, average weight and number of marketable fruit of individual cultivars depended on weather conditions in the years of the study. In 2005 and 2006, the marketable yield of 'Charentais $F_{1}$ ' was the highest, 'Melba' the lowest. The differences were 1.12 and $0.52 \mathrm{~kg} \mathrm{~m}^{-2}$ in 2005 and 2006, respectively. In 2007, the highest marketable yield, on average $4.17 \mathrm{~kg} \mathrm{~m}^{-2}$, was recorded for 'Fiesta', and the yields of the remaining two cultivars were significantly smaller (Tab. 3). In 2005 and 2007 the highest average weight of marketable fruit was delivered by 'Fiesta', 0.71 and $0.91 \mathrm{~kg}$, respectively. 'Charentais $\mathrm{F}_{1}$ ' produced fruit of significantly lower weight as compared with 'Fiesta'. However, in 2006 the marketable fruit of 'Charentais $F_{1}$ ' had a significantly higher average weight in comparison to 'Fiesta' (Tab. 4). In 2005, the highest marketable fruit weight was produced by 'Charentais $\mathrm{F}_{1}$ ' in comparison with the remaining cultivars. In 2006 and 2007 'Fiesta' had the largest size of fruit. Compared with 'Fiesta', significantly lower numbers of marketable fruit were recorded for 'Melba' in 2006, and for both 'Melba' and 'Charentais $\mathrm{F}_{1}$ ' in 2007 (Tab. 5).

The kind of foliar feed formulation applied did significantly affect the level of marketable yield, average weight and number of marketable fruit (Tabs 3-5). The foliar fertilizers used in the experiment contributed to a significant increase in marketable yield in comparison to the control without foliar feeding. An increase in marketable yield associated with Florovit and Ekolist Warzywa + Urea amounted to 0.35 and $0.60 \mathrm{~kg} \mathrm{~m}^{-2}$, respectively. In all the years of the study, the marketable yield of Ekolist Warzywa + Urea fertilized melon was the highest, although significant differences were found in 2007.

A significant interaction between the kind of feeding and cultivar was found. In the treatments with foliar feeding and in the control without foliar feeding, significantly higher marketable yields were recorded for 'Charentais $F_{1}$ ' and 'Fiesta', as compared with 'Melba'. Simultaneously, in the Florovit and EkolistWarzywa + Urea fertilized plots, the marketable yield of 'Fiesta' was significantly higher than 'Charentais $\mathrm{F}_{1}$ ' and 'Melba' (Tab. 3). Kołota and Biesiada (2000) showed in their studies that the total and marketable yield of soil-fertilized carrot with half of the recommended dose, twice foliar fertilized with Ekolist PK and three times with Ekolist S, were comparable with the yield achieved in the plot where the whole NPK rate was soil-applied. The authors observed a further significant increase in carrot root yield, when complete soil fertilization was introduced. Only the plot which was fivefold fertilized with Ekolist S. Rożek et al. (2000) harvested the highest and best quality total yield of carrot roots from the plots, in which half the mineral nitrogen rate was soil-applied and combined with foliar feeding. The lowest yields were obtained from the plots with natural nitrogen content in the soil and no foliar feeding. In a study by Osińska and Kołota (1998), foliar fertilization with Ekolist, applied four times at a concentration of 1.5\%, 
increased the marketable yield of cabbage, cucumber, and onion by 20.3, 7.3 and $10.8 \%$, respectively, when the soil-applied rate of nitrogen was reduced by half. Kołota and Osińska (2000) received the maximum tomato yield from plots fertilized with half of the recommended MIS-4 rate and foliar fed with Ekolist S. Such a system of fertilization enhanced the marketable yield of fruit by $9.8 \%$ and early yield by $11.3 \%$. Biesiada and Kołota (2001) showed that the preplant application of half the NPK rate combined with sprayings with Ekolist PK and Ekolist S did significantly increase the yields of white cabbage as compared with the non-fertilized control. The increase in marketable yield ranged from 5.2 to 9.4\% in comparison with the soil-fertilized treatments.

An interaction between the kind of foliar feed and cultivar on average weight of marketable fruit was found. In the control, a significantly higher average weight of 'Melba' fruit was recorded as compared with 'Charentais $\mathrm{F}_{1}$ '. In the Florovit and Ekolist Warzywa + Urea fertilized treatments the biggest fruit was produced by 'Fiesta' in comparison with the remaining cultivars (Tab. 4). Osińska and Kołota (2002) demonstrated that foliar feeding of crisphead lettuce increased the unit weight of marketable lettuce by $30.7 \%$. However, Kowalska et al. (2006) showed that foliar feeding had no significant effect on lettuce head weight and yield.

The foliar fertilizers applied in the experiment significantly increased the number of marketable fruit in comparison with the control. In the Florovit fertilized and Ekolist Warzywa + Urea fertilized plots the mentioned yield amounted to 0.30 and 0.31 fruit per $\mathrm{m}^{2}$, respectively (Tab. 5). In the study by Mareczek et al. (2000), the number of marketable fruit of pumpkin was significantly higher following the foliar application of Supervit K, as compared with Microvit 2 and Urea.

Weather conditions in the subsequent years significantly influenced melon fruit flesh thickness and flavour (Tabs 6 and 7). The flesh of the fruit harvested in 2005 and 2006 was thicker than in 2007. Fruit flavour in 2005 was ranked significantly higher, by 0.29 on average, compared with 2007 .

In 2005, the thickest flesh characterised 'Charentais $F_{1}$ ', whereas the flesh of 'Melba' was significantly thinner (by $4.2 \mathrm{~mm}$ ). In 2007, the flesh of 'Fiesta' was the thickest, whereas the flesh of both remaining cultivars was significantly thinner (Tab. 6).

In 2005 and 2006 the highest ranking for fruit flavour, 5.83 and 5.44 respectively, was given to 'Fiesta' (Tab. 7). In 2005, the flavour of 'Melba' was significantly poorer, as compared with 'Fiesta', and in 2006 the flavour of both remaining cultivars was as well. In 2007, the fruit of 'Charentais $F_{1}$ ' was the tastiest (fruit flavour 5.67) in comparison with the remaining cultivars. 
Table 6. Flesh thickness depending on cultivar of melon and foliar feeding (mm)

\begin{tabular}{lccccc}
\hline \multirow{2}{*}{ Year } & \multirow{2}{*}{ Foliar feeding } & \multicolumn{3}{c}{ Cultivar } & \multirow{2}{*}{ Mean } \\
\cline { 3 - 5 } 2005 & I* & 34.3 & 'Melba' & 'Fiesta' & \\
\hline \multirow{2}{*}{20.0} & 28.0 & 26.3 & 28.0 & 29.5 \\
& II & 30.7 & 27.3 & 30.7 & 28.5 \\
\hline \multirow{2}{*}{2006} & III & 31.0 & 26.8 & 30.7 & 29.6 \\
\hline \multirow{2}{*}{ Mean } & I & 30.3 & 32.3 & 29.8 & 29.2 \\
\hline \multirow{2}{*}{2007} & II & 30.0 & 32.3 & 29.3 & 30.0 \\
& III & 33.0 & 30.3 & 31.0 & 30.5 \\
& & 31.1 & 31.6 & 29.2 & 30.6 \\
\hline \multirow{2}{*}{ Mean } & I & 22.3 & 19.0 & 35.3 & 25.5 \\
\multirow{2}{*}{ Mean for } & II & 28.7 & 19.3 & 36.0 & 28.0 \\
foliar feeding & III & 26.0 & 23.7 & 38.3 & 29.3 \\
\hline Mean for cultivar & II & 25.7 & 20.7 & 36.5 & 27.6 \\
\hline
\end{tabular}

$\mathrm{LSD}_{0.05}$ for: years $=1.6$; foliar feeding $=1.6$; cultivar $=2.2$; year $\times$ foliar feeding $=$ n.s.;

year $\times$ cultivar $=3.8$; foliar feeding $\times$ cultivar $=$ n.s.

*Explanations: see Table 3

Table 7. Fruit flavour depending on cultivar of melon and foliar feeding (scale 1-6)

\begin{tabular}{|c|c|c|c|c|c|}
\hline \multirow{2}{*}{ Year } & \multirow{2}{*}{ Foliar feeding } & \multicolumn{3}{|c|}{ Cultivar } & \multirow{2}{*}{ Mean } \\
\hline & & 'Charentais $\mathrm{F}_{1}$ ' & 'Melba' & 'Fiesta' & \\
\hline \multirow{3}{*}{2005} & $\mathrm{I}^{*}$ & 5.5 & 3.2 & 5.7 & 4.8 \\
\hline & II & 5.5 & 3.8 & 5.8 & 5.1 \\
\hline & III & 5.7 & 3.7 & 6.0 & 5.1 \\
\hline \multirow[t]{2}{*}{ Mean } & & 5.6 & 3.6 & 5.8 & 5.0 \\
\hline & I & 4.8 & 4.5 & 5.0 & 4.8 \\
\hline \multirow[t]{2}{*}{2006} & II & 4.7 & 4.2 & 5.3 & 4.7 \\
\hline & III & 5.0 & 4.5 & 6.0 & 5.2 \\
\hline \multirow[t]{2}{*}{ Mean } & & 4.8 & 4.4 & 5.4 & 4.9 \\
\hline & I & 5.5 & 3.2 & 6.0 & 4.9 \\
\hline \multirow[t]{2}{*}{2007} & II & 5.7 & 3.3 & 4.5 & 4.5 \\
\hline & III & 5.8 & 3.5 & 4.7 & 4.7 \\
\hline Mean & & 5.7 & 3.3 & 5.1 & 4.7 \\
\hline \multirow{3}{*}{$\begin{array}{l}\text { Mean for } \\
\text { foliar feeding }\end{array}$} & I & 5.2 & 3.6 & 5.6 & 4.8 \\
\hline & II & 5.3 & 3.8 & 5.2 & 4.8 \\
\hline & III & 5.5 & 3.9 & 5.6 & 5.0 \\
\hline \multicolumn{2}{|l|}{ Mean for cultivar } & 5.3 & 3.8 & 5.5 & 4.9 \\
\hline
\end{tabular}


Gajc-Wolska et al. (2004) carried out studies regarding sensory assessment of melon fruit and found significant differences between cultivars in respect of the following quantitative attributes: smell, texture, flesh hardness and succulence, and taste. 'Fiesta', 'Pulsar' and 'Pacstart' were ranked higher in terms of sweetness and melon smell compared with the fruit of 'Yuma' and 'Doral'. The fruit of 'Fiesta', 'Pulsar' and 'Pacstart' were also ranked high in terms of flesh succulence and intensity of melon taste. According to the authors, the overall quality of melon fruit first of all depends on smell, taste and the texture of the fruit.

The kind of foliar feed significantly affected flesh thickness. The fruit of Ekolist Warzywa + Urea fertilized plants featured significantly thicker flesh as compared with the control plants cultivated without foliar feeding. The difference amounted to $1.7 \mathrm{~mm}$. A tendency for fruit flesh thickening following Florovit application was observed; however, it was not statistically confirmed.

The fruit flavour in the treatments with foliar feeding depended on the weather conditions during the years of the study. In the years 2005 and 2007, no significant influence of the kind of foliar feed on fruit flavour was found. In 2006, the fruit of Ekolist Warzywa + Urea fertilized plants was ranked significantly higher in terms of fruit flavour (5.17).

\section{CONCLUSIONS}

1. Higher yield of better quality fruit was achieved in the years with relatively high air temperature and low rainfall towards the end of the growing period of melon.

2. Application of Ekolist Warzywa + Urea increased marketable yield, flesh thickness and fruit flavour as compared with Florovit feeding. Foliar feeding with both studied formulations increased the average fruit weight and number of marketable fruit as compared to the non-fertilized melons.

3. The cultivar 'Fiesta', which yielded well under the soil-climatic conditions of central-eastern Poland, produced the highest marketable yield and the best quality fruit.

\section{REFERENCES}

BiesiadA A., KoŁOTA E., 2001. Wpływ nawożenia dolistnego na plonowanie kapusty głowiastej białej. Ogólnopol. Konf. Nauk. „Biologiczne i agrotechniczne kierunki rozwoju warzywnictwa”. Skierniewice, 21-22 czerwca: 86-88. 
Biesiada A., KoŁota E., OsiŃsKa M., MichalaK K., 2000. Wpływ nawożenia dolistnego na wybrane wskaźniki wartości odżywczej warzyw. Zesz. Nauk. AR w Krakowie 364: 53-56.

CzubA R., 1993. Efekty dolistnego dokarmiania roślin uprawnych. Cz. 1. Reakcje roślin na dolistne stosowanie azotu. Roczn. Glebozn. 44(3/4): 69-78.

GAJC-WOLSKa J., WĘGLARZ Z., RADZANOWSKa J., 2004. Sensory characteristics of fruit of selected cultivars of musk melon (Cucumis melo L.) from the field production. Zesz. Probl. Post. Nauk Roln. 497: 231-236.

KoŁota E., Biesiada A., 2000. The effect of foliar fertilization on yield and quality of carrot roots. Roczn. AR w Poznaniu CCCXXIII, Ogr. 31(1): 331-335.

KоŁotA E., OsIŃSKA M., 2000. The effect of foliar nutrition on yield of greenhouse tomatoes and quality of the crop. Acta Physiol. Plant. 22(3): 373-376.

KOWALSKA I., SADY W., SZURA A., 2006. Effects of nitrogen form, foliar nutrition and growing place on yield and quality of lettuce. Acta Agroph. 7(3): 619-631.

MARECZEK A., RożEK S., SADY W., 2000. Wpływ pozakorzeniowego dokarmiania roślin na wielkość i jakość plonu dyni. Zesz. Nauk. AR w Krakowie 364: 131-134.

MAZUR Z., 1992. Wpływ nawożenia azotowego na poziom zawartości azotanów i azotynów w warzywach. Biul. Warz. 38: 123-139.

NURZYŃSKI J., 1997. Pozakorzeniowe stosowanie nawozów mineralnych. VI Konf. Katedr Uprawy Roli i Nawożenia Roślin Ogrodniczych „Nawożenie roślin ogrodniczych - stan badań i kierunki rozwoju”. Kraków, 20-21 czerwca: 27-31.

OsiŃSKA M., KoŁotA E., 1998. Utilization of Ekolist in foliar nutrition of field vegetable crop grown at different nitrogen rates. Folia Univ. Agric. Stetin., Agricult. 190(72): 247-252.

OsiŃSKA M., KoŁOTA E., 2002. Wpływ stosowanych dolistnie nawozów wieloskładnikowych na plonowanie sałaty głowiastej. Ogólnopol. Konf. Nauk. „Jakość warzyw i ziół na tle uwarunkowań uprawowych i pozbiorczych”. Warszawa, 27-28 czerwca: 69-70.

ROŻEK S., SADY W., KASPRZAK A., 2000. Wpływ pozakorzeniowego dokarmiania roślin na wielkość i jakość plonu marchwi. Zesz. Nauk. AR w Krakowie 364: 159-162.

SADY W., 2000. Nawożenie warzyw polowych. Plantpress, Kraków.

Trejo-Téllez L.I., RodrigueZ-Mendoza M.N., AlCÁNTAR-GonZÁlez G., GÓMEZ-MERINO F.C., 2007. Effect of foliar fertilization on plant growth and quality of Mexican Husk Tomato (Physalis ixocarpa Brot.). Acta Hort. 729: 295-299. 
WóJCIK P., 1998. Pobieranie składników mineralnych przez części nadziemne roślin z nawożenia pozakorzeniowego. Post. Nauk Roln. 1: 49-64.

\section{WPŁYW DOKARMIANIA DOLISTNEGO NA PLON I JAKOŚĆ OWOCÓW TRZECH ODMIAN MELONA (CUCUMIS MELO L.)}

Streszczenie: Badano wpływ dokarmiania dolistnego nawozami płynnymi: Florovit i Ekolist Warzywa $\mathrm{z}$ dodatkiem mocznika na wielkość i jakość plonu trzech średnio owocowych odmian melona ('Charentais $F_{1}$ ', 'Melba', 'Fiesta'). Warunki pogodowe $\mathrm{w}$ poszczególnych latach badań miały istotny wpływ na wysokość i jakość plonu owoców. Większy i lepszy jakościowo plon owoców uzyskano w latach 2005 i 2007, charakteryzujących się dość wysoką temperaturą powietrza i małą ilością opadów w końcowym okresie wegetacji melona. Użyte $\mathrm{w}$ doświadczeniu nawozy istotnie wpłynęły na plonowanie melona. Z roślin dokarmianych nawozem Ekolist Warzywa $\mathrm{z}$ dodatkiem mocznika zebrano większy plon handlowy owoców melona niż $\mathrm{z}$ roślin dokarmianych Florovitem. Zastosowanie tego nawozu powodowało także wzrost grubości miąższu i polepszało smakowitość owoców w porównaniu do Florovitu. Dokarmianie badanymi nawozami sprzyjało wzrostowi średniej masy oraz liczby owoców handlowych w porównaniu do roślin nie nawożonych dolistnie. 